\author{
К Л I Н I Ч Н А Б I О X I М I Я \\ Т А В Е Т Е И НА РНА МЕДИЦИНА
}

УДК 636.09:636.4

doi: 10.36359/scivp.2019-20-2.09

\title{
ЕФЕКТИВНІСТЬ БІОЛОГІЧНО АКТИВНОГО ТКАНИННОГО ПРЕПАРАТУ ПРИ ВИРОЩУВАННІ ПОРОСЯТ
}

\author{
I. Я. Коиюмбас ${ }^{1}$, д-р вет. наук, професор, академік НААН, \\ М. І. Жила ${ }^{l}$, д-р вет. наук, дочент,

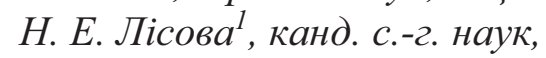 \\ А. В. Галкін ${ }^{2}$, лікар ветмедииини, \\ О. В. Михалюк ${ }^{l}$, молодший науковий співробітник, \\ Г. М. Михалусь ${ }^{1}$, науковий співробітник
}
${ }^{1}$ Державний науково-дослідний контрольний інститут ветеринарних препаратів та кормових добавок, вул. Донецька, 11, м. Львів, 79019, Україна
${ }^{2}$ ТОВ «Зооветеринарний центр»,

вул. Свободи 11, смт. Чкаловське, Чугуївський район, Харківська область, 63544, Україна

У статті представлені дані щзодо вивчення ефективності тканинного препарату "Спленотон", який містить комплекс біологічно активних речовин ліпофільної фракції тканин селезінки великої рогатої худоби і є новою розробкою серед тканинних препаратів. "Спленотон" застосовували відлученим поросятам з ознаками гіпотрофії. Як показали результати проведених досліджень, препарат у рекомендованому виробником дозуванні, способі та кратності застосування не викликав місиевих та загальних побічних реакиій. 3 а даними лабораторних досліджень зразків крові поросят, "Спленотон" не проявляв імунотоксичної, гепатотоксичної та нефротоксичної дї. Препарат добре переносився тваринами, сприяв збільшенню маси тіла поросят та помірній активації гемопоезу.

Ключові слова: ПОРОСЯТА, ГЕМАТОЛОГІЧНІ, ІМУНОЛОГІЧНІ, БІОХІМІЧНІ ПОКАЗНИКИ, ТКАНИННИЙ ПРЕПАРАТ.

Серед біологічно активних препаратів, що знайшли широке застосування у ветеринарній медицині, є засоби, виготовлені з тканин тварин або рослин. Тканинні препарати - біогенні речовини, які стимулюють обмін речовин, активують захисні та регенераторні функції організму. Хімічна будова і механізм дії біогенних стимуляторів остаточно не з'ясовані. Аналіз літературних даних свідчить, що склад тканинних препаратів залежить від видової специфічності, тому характерною особливістю таких засобів є здатність забезпечувати широкий спектр фармакологічної, терапевтичної дії та підвищення реактивності організму у тварин [1].

Однією із важливих властивостей тканинних препаратів $є$ відсутність побічних ефектів за їх дії на організм. Вони не мають анафілактичних властивостей, не спричиняють звикання і патологічної сенсибілізації, не змінюють антитоксичної функції печінки, є апірогенними, не 
акумулюються організмом, не проявляють антагоністичних та канцерогенних властивостей [2, 3]. Тканинні препарати легко проникають крізь клітинні мембрани та біологічні бар'єри у внутрішньоклітинне середовище, відновлюють та нормалізують тканинний обмін речовин в організмі, активують метаболічні окисно-відновні процеси в організмі тварин. Установлено, що застосування тканинних препаратів дає змогу підтримувати нормальне функціонування підшлункової залози, забезпечує засвоєння ліпідів і жиророзчинних сполук, попереджає ожиріння печінки, нормалізуючи функції загальної утилізації жиру в організмі у перший період постнатального розвитку молодняку свиней та великої рогатої худоби [4-6].

Рекомендований ТОВ "Зооветеринарний центр" (Україна) тканинний препарат "Спленотон", що містить комплекс біологічно активних речовин, належить до нових розробок цієї групи препаратів, які застосовуються 3 метою підвищення інтенсивності росту та стимуляції процесів життєдіяльності організму молодняку сільськогосподарських тварин, для зміцнення імунної системи, підвищення резистентності тварин, профілактики анемії, гепатодистрофій, стресу. Тому метою нашої роботи було вивчення терапевтичної ефективності та безпечності при застосуванні цього препарату поросятам на відгодівлі.

Матеріали і методи. Дослід проведено в Навчально-науковому виробничому центрі Львівського національного університету ветеринарної медицини і біотехнологій імені С. 3. Гжицького "Комарнівський" (с. Переможне. Городоцького району, Львівської області).

При обстеженні поголів'я поросят після відлучення, породи Велика біла, було відібрано тварин віком 1,5-2 місяці, у яких спостерігали відставання в рості, погіршення апетиту, ознаки анемічного стану. 3 відібраних поросят було сформовано та відокремлено дослідну групу чисельністю 10 тварин (1 група). Поросятам цієї групи застосовували препарат "Спленотон", у спосіб та дозі, рекомендованих виробниками, згідно з настановою по застосуванню: внутрішньом'язово триразово, в дозі 1,0 мл на 10 кг маси тіла 3 інтервалом 48 годин. 2 група тварин (контрольна) була клінічно здоровою та отримувала плацебо - ізотонічний розчин натрію хлориду 0,9 \% внутрішньом'язово, в дозі 1,0 мл на 10 кг маси тіла. Тварини обох груп мали вільний доступ до корму та води.

До застосування та на 14 добу після застосування препарату в тварин дослідної та контрольної груп відбирали зразки крові для подальшого визначення морфологічних, імунологічних та біохімічних показників у лабораторії клініко-біологічних досліджень ДНДКІ ветпрепаратів та кормових добавок за загальноприйнятими методиками [7-9]. Для морфологічних досліджень використовували стабілізовану EDTA кров, а для біохімічних досліджень - сироватку крові (СК).

Гематологічні дослідження (кількість еритроцитів, лейкоцитів, вміст гемоглобіну, гематокрит) проводили за допомогою автоматичного аналізатора Mythic 18 Vet 3 використанням принципу імпедансометрії. Загальний вміст білка в СК і визначали за допомогою рефрактометра IРФ-22. Фракційний склад білків СК визначали методом електрофорезу на ацетаті целюлози за допомогою приладу для мікрозонального електрофорезу Scan Power 300 та Scanion Lira 400, Hospitex Diagnostics. Кількісне визначення білків проводили шляхом сканування електрофореграм, з подальшим реконструюванням їх графічно та обчисленням за площею. Сумарний вміст білкових фракцій приймали за 100 \%. Фагоцитарну активність лейкоцитів оцінювали за Чумаченком $\mathrm{B}$. B. Для оцінки функціональної активності нейтрофільних гранулоцитів використали показники, які визначали традиційними методами: фагоцитарну активність нейтрофілів (ФАН), фагоцитарний індекс (ІФ, інтенсивність фагоцитозу). Здатність нейтрофільних гранулоцитів до фагоцитозу оцінювали за такими показниками: індекс Гамбургера (процент нейтрофілів, які беруть участь у фагоцитозі), індекс Райта (середнє число мікробів, захоплених одним лейкоцитом). Оцінку фагоцитозу in vitro проводили через 30 хв. після початку інкубації 3 культурою мікроорганізмів E. coli. Про інтенсивність фагоцитозу судили за показником фагоцитарного індекса. Вміст креатиніну, сечовини, заліза та залізозв'язуючу активність 
сироватки крові, активність ферментів (АлАТ i АсAT), визначали за допомогою напівавтоматичного біохімічного аналізатора (HumaLyzer 3000) з використанням тест-наборів фірми Human.

Отримані результати обробляли статистично, оцінюючи вірогідність різниці показників $(\mathrm{p}<0,05$,$) за критерієм Стьюдента. В усіх досліджуваних показниках визначали$ середньоарифметичну величину (M), середню помилку середньоарифметичної величини (m) константним методом, і критерій достовірності (p). За статистично-достовірний результат брали різницю між величинами, при якій рівень імовірності різниці (р) був не більше 0,05 , що є загальноприйнятим підходом у лабораторних дослідженнях [10-11].

Результати й обговорення. За період дослідження серед тварин як 1, так і 2 груп загибелі та захворювання не відмічали. Після застосування препарату "Спленотон" побічних реакцій у місці введення не виявляли, а показники загального клінічного стану (температура, пульс, дихання) та лабораторних досліджень крові відповідали фізіологічним параметрам для даної вікової групи. Тварини обох груп були активними, апетит збережений. На 14 добу спостереження встановлено достовірне збільшення маси тіла поросят у дослідній групі,

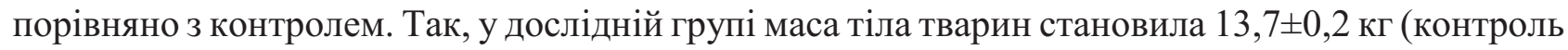
$12,4 \pm 0,1$ кг).

За лабораторними дослідженнями крові, у поросят 1 групи перед застосуванням спленотону відзначено нижчі, ніж у контрольних тварин, показники вмісту гемоглобіну, кількості еритроцитів, кількості заліза в СК (табл. 1, 2).

На 14 добу після застосування препарату "Спленотон" гематологічними дослідженнями у поросят 1 (дослідної) групи встановлено підвищення рівня гемоглобіну на 6,9 \%, кількості еритроцитів - на $11,3 \%$.

Таблиия 1

Гематологічні показники поросят при застосуванні препарату "Спленотон", $(\mathrm{M} \pm \mathrm{m}, \mathrm{n}=10)$

\begin{tabular}{|c|c|c|c|c|}
\hline Показники & Групи & $\begin{array}{c}\text { До } \\
\text { застосування }\end{array}$ & Після застосування & $\begin{array}{c}\text { Фізіологічна } \\
\text { норма }\end{array}$ \\
\hline \multirow{2}{*}{ Гемоглобін, г/л } & 1 Дослідна & $107,6 \pm 3,7$ & $118,0 \pm 2,7^{*}$ & \multirow{2}{*}{$90-120$} \\
\hline & 2 Контрольна & $112,6 \pm 3,1$ & $116,0 \pm 3,6$ & \\
\hline \multirow{2}{*}{ Еритроцити, Т/л } & 1 & $6,2 \pm 0,3$ & $6,9 \pm 0,3$ & \multirow{2}{*}{$5-8$} \\
\hline & 2 & $6,7 \pm 0,1$ & $7,0 \pm 0,2$ & \\
\hline \multirow{2}{*}{ Гематокрит, \% } & 1 & $37,0 \pm 2,4$ & $39,9 \pm 1,0$ & \multirow{2}{*}{$35-43$} \\
\hline & 2 & $38,8 \pm 0,8$ & $39,0 \pm 1,9$ & \\
\hline \multirow{2}{*}{$\mathrm{MCHC}$, г/дл } & 1 & $29,0 \pm 1,1$ & $28,7 \pm 0,5$ & \multirow{2}{*}{$30-34$} \\
\hline & 2 & $28,9 \pm 0,2$ & $29,6 \pm 0,9$ & \\
\hline \multirow{2}{*}{$\mathrm{MCV}$, мкм $^{3}$} & 1 & $59,5 \pm 0,7$ & $57,6 \pm 0,9$ & \multirow{2}{*}{$50-68$} \\
\hline & 2 & $57,5 \pm 0,2$ & $55,6 \pm 1,2$ & \\
\hline \multirow{2}{*}{ МCH, пг } & 1 & $17,3 \pm 0,9$ & $16,5 \pm 0,2$ & \multirow{2}{*}{$17-23$} \\
\hline & 2 & $16,6 \pm 0,2$ & $16,2 \pm 0,2$ & \\
\hline \multirow{2}{*}{ Лейкоцити, Г/л } & 1 & $16,8 \pm 2,3$ & $14,2 \pm 1,0$ & \multirow{2}{*}{$8-16$} \\
\hline & 2 & $16,1 \pm 0,7$ & $15,7 \pm 0,9$ & \\
\hline \multirow{2}{*}{ Еозинофіли, \% } & 1 & $5,6 \pm 0,8$ & $5,2 \pm 0,8$ & \multirow{2}{*}{$2-4$} \\
\hline & 2 & $8,0 \pm 1,2$ & $7,3 \pm 0,8$ & \\
\hline \multirow{2}{*}{ Паличкоядерні нейтрофіли, \% } & 1 & $7,6 \pm 0,7$ & $6,4 \pm 0,4$ & \multirow{2}{*}{$8-10$} \\
\hline & 2 & $6,7 \pm 0,01$ & $6,0 \pm 1,2$ & \\
\hline \multirow{2}{*}{ Сегментоядерні нейтрофіли, \% } & 1 & $36,0 \pm 3,0$ & $36,0 \pm 1,5$ & \multirow{2}{*}{$30-38$} \\
\hline & 2 & $33,3 \pm 2,7$ & $35,3 \pm 1,5$ & \\
\hline \multirow{2}{*}{ Моноцити, \% } & 1 & $5,2 \pm 0,6$ & $5,2 \pm 0,6$ & \multirow{2}{*}{$2-6$} \\
\hline & 2 & $4,7 \pm 0,8$ & $5,3 \pm 0,8$ & \\
\hline \multirow{2}{*}{ Лімфоцити, \% } & 1 & $45,6 \pm 2,8$ & $47,2 \pm 0,7$ & \multirow{2}{*}{$40-50$} \\
\hline & 2 & $48,0 \pm 3,5$ & $46,0 \pm 3,5$ & \\
\hline
\end{tabular}

Примітка: у цій і в наступних таблицях: * - p $\leq 0,05$ у порівнянні з періодом до застосування препарату 
За результатами біохімічних досліджень СК поросят дослідної групи (табл. 2), виявлено підвищення вмісту загального білка на 9,3 \%, залізозв'язуючої активності СК - на 12,9 \%, в порівнянні з попереднім визначенням. При цьому вміст заліза в СК поросят підвищився на $15 \%$. Отримані дані вказували на помірну активацію гемопоезу у поросят 1 групи після застосування досліджуваного препарату.

При застосуванні "Спленотону" не виявлено змін активності ферментів переамінування АлАТ і АсАт. Відзначено зниження вмісту сечовини та підвищення вмісту креатиніну в СК поросят, але ці зміни відбувалися в організмі поросят як дослідної, так і контрольної груп, тому коливання показників, скоріше за все, обумовлені особливостями росту та розвитку тварин та зміною режиму годівлі.

Біохімічні показники крові поросят при застосуванні препарату "Спленотон", (M $\pm \mathrm{m}, \mathrm{n}=10)$

\begin{tabular}{|c|c|c|c|c|}
\hline Показники & Групи & До застосування & Після застосування & Фізіологічна норма \\
\hline \multirow{2}{*}{ Загальний білок, г/л } & 1 & $54,8 \pm 2,9$ & $59,9 \pm 1,6^{*}$ & \multirow{2}{*}{$50-70$} \\
\hline & 2 & $57,0 \pm 2,3$ & $55,2 \pm 5,7$ & \\
\hline \multirow{2}{*}{ АлАТ, Од/л } & 1 & $52,0 \pm 2,8$ & $55,6 \pm 3,0$ & \multirow{2}{*}{$32-84$} \\
\hline & 2 & $48,9 \pm 1,4$ & $51,8 \pm 3,2$ & \\
\hline \multirow{2}{*}{ АсАТ, Од/л } & 1 & $61,5 \pm 4,5$ & $60,7 \pm 3,1$ & \multirow{2}{*}{$9-113$} \\
\hline & 2 & $56,6 \pm 2,3$ & $56,5 \pm 2,1$ & \\
\hline \multirow{2}{*}{ Сечовина, ммоль/л } & 1 & $8,0 \pm 0,4$ & $5,2 \pm 0,2 *$ & \multirow{2}{*}{$3,0-6,0$} \\
\hline & 2 & $7,9 \pm 1,1$ & $4,7 \pm 0,2 *$ & \\
\hline \multirow{2}{*}{ Креатинін, мкмоль/л } & 1 & $91,3 \pm 1,5$ & $142,8 \pm 3,0^{*}$ & \multirow{2}{*}{$100-200$} \\
\hline & 2 & $93,9 \pm 1,8$ & $147,1 \pm 3,4^{*}$ & \\
\hline \multirow{2}{*}{ Залізо, мкмоль/л } & 1 & $20,0 \pm 0,9$ & $29,0 \pm 1,1^{*}$ & \multirow{2}{*}{$16,2-35,6$} \\
\hline & 2 & $24,9 \pm 6,2$ & $24,1 \pm 1,8$ & \\
\hline \multirow{2}{*}{$\begin{array}{c}\text { Залізозв“язуюча активність } \\
\text { СК, мкмоль/л }\end{array}$} & 1 & $78,1 \pm 2,9$ & $88,2 \pm 1,4^{*}$ & \multirow{2}{*}{$>65$} \\
\hline & 2 & $74,8 \pm 2,0$ & $81,1 \pm 1,5$ & \\
\hline
\end{tabular}

Імунологічні показники сироватки крові поросят після застосування спленотону вказували на ефективність проведеного лікування та поступове відновлення фізіологічного стану тварин дослідної групи. Так, за отриманими даними (табл. 3), у поросят дослідної групи на 14 добу спостереження відзначали достовірне збільшення вмісту $\gamma$-глобулінів у сироватці крові, в порівнянні з періодом до застосування препарату, тоді як у поросят контрольної групи цей показник був нижчим і динаміка змін менш виражена.

Таблиия 3

Імунологічні показники крові поросят при застосуванні препарату Спленотон, $(\mathrm{M} \pm \mathrm{m}, \mathrm{n}=10)$

\begin{tabular}{|c|c|c|c|c|}
\hline Показники & Групи & До лікування & Після лікування & Фізіологічна норма \\
\hline \multirow{2}{*}{$\begin{array}{c}\text { Білкові фракції: } \\
\text { альбумін, \% }\end{array}$} & 1 & $34,9 \pm 1,0$ & $32,4 \pm 1,0$ & \multirow{2}{*}{$40-55$} \\
\hline & 2 & $34,9 \pm 3,0$ & $39,8 \pm 4,6$ & \\
\hline \multirow{2}{*}{$\alpha_{1}$-глобуліни, \% } & 1 & $1,2 \pm 0,06$ & $1,9 \pm 0,2$ & \multirow{2}{*}{$1-5$} \\
\hline & 2 & $1,7 \pm 0,2$ & $1,4 \pm 0,2$ & \\
\hline \multirow{2}{*}{$\alpha_{2}$ глобуліни, \% } & 1 & $17,8 \pm 1,5$ & $15,6 \pm 0,8$ & \multirow{2}{*}{$10-15$} \\
\hline & 2 & $21,5 \pm 2,0$ & $17,9 \pm 1,2$ & \\
\hline \multirow{2}{*}{$\beta$-глобуліни, \% } & 1 & $17,0 \pm 1,1$ & $13,8 \pm 1,7$ & \multirow{2}{*}{$10-20$} \\
\hline & 2 & $15,7 \pm 0,5$ & $11,4 \pm 1,3$ & \\
\hline \multirow{2}{*}{ 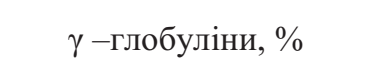 } & 1 & $29,2 \pm 1,9$ & $36,3 \pm 1,1^{*}$ & \multirow{2}{*}{$20-35$} \\
\hline & 2 & $26,2 \pm 0,8$ & $30,9 \pm 5,4$ & \\
\hline \multirow{2}{*}{$\begin{array}{c}\text { Фагоцитарна активність } \\
\text { нейтрофілів, \% }\end{array}$} & 1 & $26,4 \pm 1,1$ & $34,7 \pm 1,8^{*}$ & \multirow{2}{*}{$20-40$} \\
\hline & 2 & $30,1 \pm 1,8$ & $31,4 \pm 1,5$ & \\
\hline \multirow{2}{*}{ Фагоцитарний індекс } & 1 & $8,1 \pm 0,4$ & $9,9 \pm 0,3^{*}$ & \multirow{2}{*}{$7-20$} \\
\hline & 2 & $9,0 \pm 0,2$ & $9,1 \pm 0,5$ & \\
\hline
\end{tabular}


Також у поросят 1 групи відзначено достовірні зміни показника клітинного фактору неспецифічної резистентності. Вищі значення як за показником фагоцитарної активності нейтрофілів, так і фагоцитарного індексу свідчили про активацію природного імунітету та підсилення протимікробного захисту організму.

Отже, отримані морфологічні, окремі імунологічні та біохімічні показники крові вказували на ефективність препарату "Спленотон" та безпечність його застосування поросятам з ознаками порушення обмінних процесів, резистентності та відставання в рості.

\title{
В И С Н О В К И
}

1. Отримані результати проведених клінічних досліджень препарату "Спленотон", розчин для ін'єкцій, виробництва ТОВ "Зооветеринарний центр" (Україна), вказували на його ефективність при застосуванні поросятам з ознаками гіпотрофії, що проявлялася покращенням загального клінічного стану організму, зростанням маса тіла поросят, активацією процесів кровотворення та імунного захисту і стабілізацією фізіологічних параметрів організму.

2. При застосуванні препарату "Спленотон" у рекомендованому виробником дозуванні, способі та кратності застосування не встановлено імунотоксичної, гепатотоксичної та нефротоксичної дії на організм молодняка свиней. Препарат добре переносився тваринами, не викликав місцевих та загальних побічних реакцій.

Перспективи досліджень. Вивчити вплив препарату на організм поросят в комплексній терапії шлунково-кишкових, респіраторних захворювань, а також після дегельмінтизації.

\section{EFFICIENCY BIOLOGICALLY ACTIVE TISSUE PREPARATION AT GROWING OF PIGLETS}

\author{
I. Ya. Kotsyumbas ${ }^{1}$, M. I. Zhyla ${ }^{1}$, N. E. Lisoval , A. V. Halkin ${ }^{2}$, O. V. Mychalyuk ${ }^{1}$, G. M. Mychalus ${ }^{1}$
}

${ }^{1}$ State Scientific-Research Control Institute of Veterinary Medicinal Products and Feed Additives 11, Donetska str., Lviv, 79019, Ukraine

${ }^{2}$ «ZooVeterinary Center» Ltd,

11, Svobody str., smt. Chkalovske, Chuguevsky district, Kharkiv region, 63544, Ukraine

\section{S U M M A R Y}

Biologically active preparations, mainly of tissue origin, are widely used in the practice of veterinary medicine. Analysis of literary data shows that the elemental composition of tissue preparations depends on species specificity, therefore the characteristic feature of such means is the ability to provide a wide range of pharmacological action and increase the reactivity of the organism. The preparation of the Splenoton, a solution for injections, manufactured by Zooveterynny Center LLC, contains a complex of biologically active substances (nucleotides, lipids, peptides, vitamins, organic acids and other biologically active substances), which are represented by the lipophilic fraction of the tissues of the spleen of cattle.

The purpose of the study was to investigate the therapeutic efficacy and safety of the Splenoton. The task of the study was to establish the therapeutic effect of the use of the drug for piglets with signs of hypotrophy, as well as to study its effect on the basic morphological, immunological and biochemical parameters of blood of animals. For morphological studies, stabilized EDTA blood was used, and for blood biochemical studies - serum. Morphological parameters of blood of piglets were determined using the automatic analyzer Mythic 18 Vet, biochemical - using a biochemical analyzer (HumaLyzer 3000) using human test kits. 
When examining the number of piglets after weaning, the breed "Big White" was selected a group of animals (10 heads) aged 1,5-2 months, in which observed lag in growth, deterioration of appetite, signs of anemia state. From the selected piglets, an experimental group of animals was formed which used the compound of the Splenoton intramuscularly at a dose of $1,0 \mathrm{ml} / 10 \mathrm{~kg}$ body weight 3 times with an interval of 48 hours. The control group of animals was clinically healthy and received an intramuscular isotonic sodium chloride solution of $0.9 \%$ at the same dose. Prior to application, and 14 days after using the Splenoton drug, animals in the experimental and control groups were examined for blood samples.

During the period of study in animals, both groups of death and disease were not noted. All indicators of the general clinical status (temperature, pulse, respiration) and laboratory blood tests corresponded to the physiological parameters for this age group. Animals of both groups were active, appetite preserved. The drug was well tolerated by animals, did not cause local and general adverse reactions.

The obtained results of the clinical studies of the preparation of Splenoton, a solution for injection, indicated its effectiveness, which was manifested by improving the overall clinical condition of the piglet's organism. On the 14th day of the experiment the body weight of animals was increased, processes of hematopoiesis were activated and physiological parameters of the organism stabilized. Preparation Splenoton, in the recommended by the manufacturer dosage, method and multiplicity of the application to young piglets, does not show immunotoxic, hepatotoxic and nephrotoxic effects.

Keywords: PIGLETS, HAEMATOLOGICAL，IMMUNOLOGICAL，BIOCHEMICAL INDEXES, TISSUE PREPARATION.

\title{
ЭФФЕКТИВНОСТЬ БИОЛОГИЧЕСКИ АКТИВНОГО ТКАНЕВОГО ПРЕПАРАТА ПРИ ВЫРАЩИВАНИИ ПОРОСЯТ
}

\author{
И. Я. Кочюмбас ${ }^{1}$, Н. И. Жила ${ }^{1}$, Н. Э. Лисовая ${ }^{1}$, А. В. Галкин ${ }^{2}$, О. В. Михалюк ${ }^{1}$ Г. М. Михалусь ${ }^{1}$ \\ ${ }^{1}$ Государственный научно-исследовательский контрольный институт ветеринарных \\ препаратов и кормовых добавок \\ ул. Донецкая, 11, г. Львов, 79019, Украина \\ ${ }^{2}$ ТОВ «Зооветеринарный центр»,
}

ул. Свободы 11, пгт. Чкаловское, Чугуевский район, Харьковская область, 63544, Украина

\section{А Н Н О Т А ЦИ Я}

В статье представлены данные изучения эффективности тканевого препарата "Спленотон", содержащего комплекс биологически активных веществ липофильной фракции тканей селезенки крупного рогатого скота и являющегося новой разработкой среди тканевых препаратов. "Спленотон" применяли отлученным поросятам с признаками гипотрофии. Как показали результаты проведенных исследований, препарат в рекомендованных производителем дозировании, способе и кратности применения не вызывал местных и общих побочных реакций. По данным лабораторных исследований образцов крови поросят, "Спленотон" не проявлял иммунотоксического, гепатотоксического и нефротоксического действия. Препарат хорошо переносился животными, способствовал увеличению массы тела поросят и умеренной активации гемопоэза.

Ключевые слова: ПОРОСЯТА, ГЕМАТОЛОГИЧЕСКИЕ, ИММУНОЛОГИЧЕСКИЕ, БИОХИМИЧЕСКИЕ ПОКАЗАТЕЛИ, ТКАНЕВОЙ ПРЕПАРАТ. 


\section{Л I T E P A T Y P A}

1. Гончаренко В. Склад тканинних препаратів, виготовлених методом П. В. Філатова / В. Гончаренко // Тваринництво України - березень-квітень, 2017. - С. 40.

2. Тютюн С. М. Перспективи застосування імуномодулюючих тканинних препаратів у тваринництві (огляд) / С. М. Тютюн // Науковий вісник Національного університету біоресурсів і природокористування України. Серія: Ветеринарна медицина, якість і безпека продукції тваринництва. - 2013. - Вип. 188(4). - С. 213-220.

3. Вплив СТП (стимулюючого тканинного препарату) на фагоцитарну активність крові

у щеплених свиней / С. М. Тютюн, О. І. Горбатюк, В. О. Андріящук та ін. // Ветеринарна біотехнологія. - 2018. - Вип. 32(2). - С. 550-556.

4. Каменчук П. П. Ефективність тканинного препарату 3 імуностимулюючими властивостями (СТП) при лікуванні фузобактеріозу великої рогатої худоби / П. П. Каменчук, В. О. Андріящук, С. М. Бєлік // Ветеринарна біотехнологія. - 2007. - № 11. - С. 52-58.

5. Квачов В. П. Імунологічні та біохімічні підходи до інтегральної оцінки здоров'я тварин / В. П. Квачов, Т. О. Сокирко // Ветеринарна біотехнологія. - Київ, 2006. - № 9. - С.104 -113 .

6. Роль тканинного активатора плазміногену та його інгібітора у функціонуванні системи гемостазу за норми та патології / Є. М. Краснобрижа, О. М. Савчук, Т. М. Платонова, Г. Л. Волков // Український біохімічний журнал.- 2004. - № 6. - С. 29-38.

7. Клінічні дослідження ветеринарних препаратів та кормових добавок / Коцюмбас І. Я., Бісюк І. Ю., Горжеєв В. М. [та ін.]; за ред. І.Я. Коцюмбаса. - Л.: ТОВ Видавничий дім «САМ», 2013. - 252 с.

8. Імунотоксикологічний контроль ветеринарних препаратів та кормових добавок: Методичні рекомендації / І. Я. Коцюмбас, М. І. Жила, О. М. П’ятничко та ін. За ред. І. Я. Коцюмбаса. - Львів, 2014. - 116 с.

9. Лабораторні методи дослідження у біології, тваринництві та ветеринарній медицині: довідник / В. В. Влізло, Р. С. Федорук, І. Б. Ратич та ін.; за ред. В. В. Влізла. - Львів: Сполом, 2012. $-764 \mathrm{c}$.

10. Мазур T. Константні методи математичної обробки кількісних показників / Т. Мазур // Ветеринарна медицина України. - 1998. - № 11. - С. 35-37.

11. Statistical principles for veterinary clinical trials. CVMP/EWP/81976/2010.

\section{References}

1. Goncharenko V. Sklad tkanynnyh preparativ, vygotovlenyh metodom P. V. Filatova. / V.Goncharenko // Tvarynnyctvo Ukrai'ny - berezen'-kviten', 2017. - C. 40.

2. Tjutjun S. M. Perspektyvy zastosuvannja imunomoduljujuchyh tkanynnyh preparativ u tvarynnyctvi (ogljad)/ S. M. Tjutjun // Naukovyj visnyk Nacional'nogo universytetu bioresursiv i pryrodokorystuvannja Ukrai'ny. Serija: Veterynarna medycyna, jakist' i bezpeka produkcii' tvarynnyctva. - 2013. - Vyp. 188(4). - S. 213-220.

3. Tjutjun S. M. Vplyv STP (stymuljujuchogo tkanynnogo preparatu) na fagocytarnu aktyvnist' krovi u shheplenyh svynej / S. M. Tjutjun, O. I. Gorbatjuk, V. O. Andrijashhuk, G. F. Ryzhenko, T. M. Uhovs'ka, O. M. Zhovnir // Veterynarna biotehnologija. - 2018. - Vyp. 32(2). - S. 550-556.

4. Kamenchuk P.P. Efektyvnist' tkanynnogo preparatu $\mathrm{z}$ imunostymuljujuchymy vlastyvostjamy (STP) pry likuvanni fuzobakteriozu velykoi' rogatoi' hudoby / P.P. Kamenchuk, V.O. Andrijashhuk, S.M. Bjelik // Veterynarna biotehnologija. - 2007. - № 11. - S. 52-58.

5. Kvachov V.P. Imunologichni ta biohimichni pidhody do integral'noi' ocinky zdorov'ja tvaryn / V.P. Kvachov, T.O. Sokyrko // Veterynarna biotehnologija. - Kyi'v, 2006. - № 9. - S.104 113. 
6. Krasnobryzha Je.M. Rol' tkanynnogo aktyvatora plazminogenu ta jogo ingibitora u funkcionuvanni systemy gemostazu za normy ta patologii' / Je.M. Krasnobryzha, O.M. Savchuk, T.M. Platonova, G.L. Volkov // Ukrai'ns'kyj biohimichnyj zhurnal.- 2004. - № 6. - S. 29-38.

7. Klinichni doslidzhennja veterynarnyh preparativ ta kormovyh dobavok / Kocjumbas I.Ja., Bisjuk I.Ju., Gorzhejev V.M., Malyk O.G. [ta in.]; za red. I.Ja. Kocjumbasa. - L.: TOV Vydavnychyj $\operatorname{dim} \ll \mathrm{SAM} », 2013 .-252 \mathrm{~s}$.

8. Imunotoksykologichnyj kontrol' veterynarnyh preparativ ta kormovyh dobavok: Metodychni rekomendacii' / I. Ja. Kocjumbas, M. I. Zhyla, O. M. P'jatnychko ta in. Za red. I. Ja. Kocjumbasa. - L'viv, 2014. - 116 s.

9. Laboratorni metody doslidzhennja u biologii', tvarynnyctvi ta veterynarnij medycyni: dovidnyk / V. V. Vlizlo, R. S. Fedoruk, I. B. Ratych ta in.; za red. V. V. Vlizla. - L'viv: Spolom, 2012. $-764 \mathrm{~s}$.

10. Mazur T. Konstantni metody matematychnoi' obrobky kil'kisnyh pokaznykiv /T.Mazur // Veterynarna medycyna Ukrai'ny. - 1998. - № 11. - S. 35-37.

11. Statistical principles for veterinary clinical trials. CVMP/EWP/81976/2010.

Рецензент - Б. В. Гутий, д. вет. н., ЛНУВМБ імені С. 3. Гжицького.

УДК 636.5.033:636.085.57:636.085.8:636.08.003

doi: $10.36359 /$ scivp.2019-20-2.10

\section{ВПЛИВ ВИПОЮВАННЯ ПІДКИСЛЮВАЧА «АКВАСАН»} НА ПРОДУКТИВНІСТЬ КУРЧАТ БРОЙЛЕРІВ

М. Д. Кухтин ${ }^{1}$, д-р вет. наук, професор,

Н. П. Болтик ${ }^{1}$, канд. с.-г. наук,

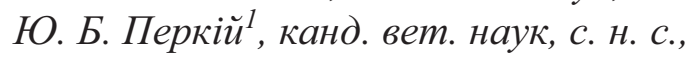

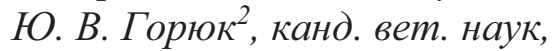

Н. М. Ворожбит ${ }^{1}$, молодший науковий співробітник,

О. В. Демчишин ${ }^{1}$, ветлікар

${ }^{1}$ Тернопільська дослідна станція Інституту ветеринарної медицини НААН вул. Тролейбусна, 12, м. Тернопіль, 46027, Україна

${ }^{2}$ Подільський державний аграрно-технічний університет

вул. Шевченка, 13, м. Кам'янець-Подільський, Хмельницька область, 32300, Україна

У статті наведено вивчення впливу застосування нового підкислювача «Аквасан» на продуктивність курчат бройлерів. Встановлено, щз з 27 дня випоювання підкислювача спостерігали зростання живої маси бройлерів аж до 42 дня вирощування. На 35 добу маса

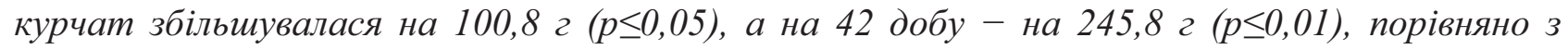
контрольною групою. У період вирощування 29-35 та 36-42 доба при застосуванні підкислювача «Аквасан» у курчат середньодобові прирости за тиждень зростали відповідно

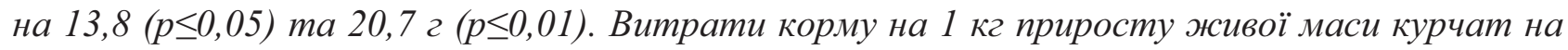

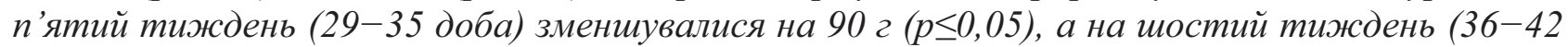

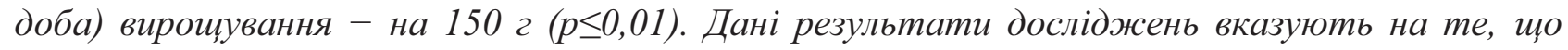

